\title{
Biogeographic variability in ecosystem engineering: patterns in the abundance and behavior of the tube-building polychaete Diopatra cuprea
}

\author{
Sarah K. Berke* \\ Smithsonian Environmental Research Center, 647 Contees Wharf Rd, Edgewater, Maryland 21037, USA
}

Present address: Department of the Geophysical Sciences, University of Chicago, 5734 S. Ellis Ave, Chicago, Illinois 60637, USA

ABSTRACT: Ecosystem engineering is an important process influencing the structure and function of ecosystems worldwide. Geographic variation in a species' engineering processes can thus have important implications for spatial heterogeneity in ecosystem function. In this study I explore geographic variability in the engineering properties of an important organism in marine sedimentary habitats, the polychaete Diopatra cuprea. In the Northwest Atlantic, D. cuprea facilitates benthic communities by creating predation refugia and substrate-both density-dependent processesand by actively attaching macroalgae to its tube. $D$. cuprea's ecosystem-engineering properties thus arise from both its abundance and its behavior. I show that both components of $D$. cuprea engineering decrease precipitously at low latitudes. I assess the relationship between these patterns and a suite of environmental parameters, finding that northern versus southern sites cluster separately in multivariate environmental space and that temperature, dissolved oxygen, and $\mathrm{pH}$ may contribute to both $D$. cuprea abundance and the biomass of facilitated algae. I present evidence that southern $D$. cuprea populations may be affected by post-recruitment mortality more severely than northern populations. Finally, I experimentally demonstrate that $D$. cuprea's failure to facilitate algae in its southern range is not due to latitudinal differences in algal availability, acceptability or retainability, but rather is a behavioral shift driven by still-unknown factors. This study demonstrates dramatic geographic variability in both $D$. cuprea's density - with strong implications for its density-dependent engineering functions - and D. cuprea's algal facilitation. Disentangling the mechanisms underlying such variability is an important goal for understanding spatial heterogeneity in the structure and function of Northwest Atlantic shallowwater sedimentary systems.
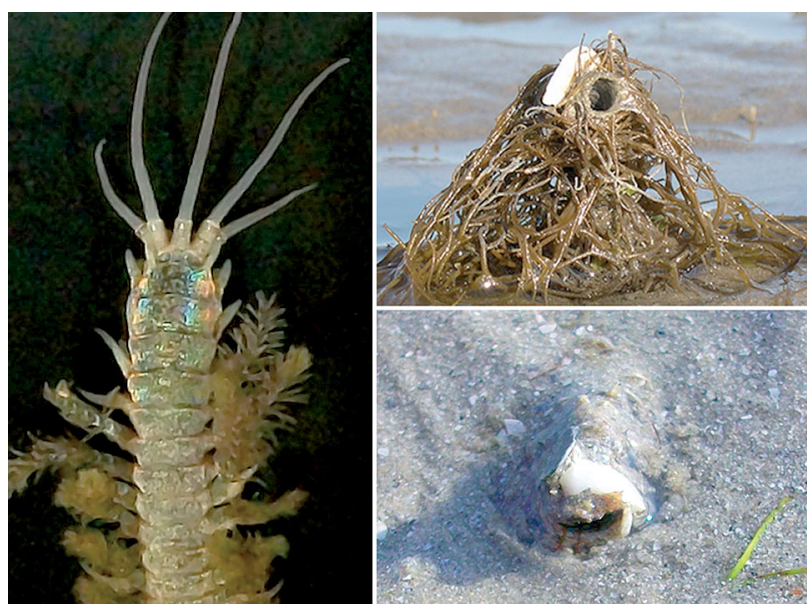

The polychaete Diopatra cuprea (left), an ecosystem engineer, typically decorates its tube with algae (top right)except in Florida (bottom right).

Photos: S. Berke

KEY WORDS: Benthic habitats - Biogenic habitat structure - Biogeographic comparison · Facilitation · Infauna · Intertidal macroalgae · Intertidal sediments · Northwest Atlantic

Resale or republication not permitted without written consent of the publisher

\section{INTRODUCTION}

Many organisms physically create or modify habitats. Such processes constitute ecosystem engineering, a fundamental class of ecological interactions occurring in most, if not all, ecosystems (Wright \& Jones 2006, Cuddington et al. 2007). Factors which 
influence variation in ecosystem engineering are important because of their potential to influence variation in ecosystem structure and function. Ecosystem engineering effects are expected to vary across environmental gradients (Cuddington \& Hastings 2004, Crain \& Bertness 2006, Wright \& Jones 2006, Wright et al. 2006). For example, cushion plants have positive effects on species diversity and evenness, but the effect size varies across $20^{\circ}$ of latitude and $2800 \mathrm{~m}$ elevation (Badano \& Cavieres 2006). Similarly, shrubs enhance species richness at several spatial scales with varying effect size depending on precipitation (Wright et al. 2006). Seagrass beds enhance the diversity and abundance of fish and decapods differently depending on bed position within an estuary (Bell \& Westoby 1986), and oyster reefs have different effects on species richness and evenness across a disturbance gradient (Kimbro \& Grosholz 2006). Although ecosystem engineering is known to vary geographically in many systems, more work is needed to document and understand large-scale patterns in such variability. Here I present a case study showing remarkable geographic variation over $15^{\circ}$ of latitude in the ecosystem-engineering properties of the polychaete Diopatra cuprea (Bosc, 1802) in intertidal marine sediments of the Northwest Atlantic.

Marine sedimentary habitats are often structured by burrowing and tube-building infauna. Tubes stabilize sediments at depth while enhancing surface erosion (Fager 1964, Eckman et al. 1981, Luckenbach 1986) and influence many benthic processes including sediment deposition, microbial activities, diffusion, advection, and recruitment (Eckman 1985, 1990, Huettel \& Gust 1992, Boudreau \& Jørgensen 2001). Onuphid polychaetes, with their large and robust tubes, are particularly important tube-builders in tropical and temperate sediments worldwide. In the eastern United States, sedimentary habitats are often dominated by the onuphid Diopatra cuprea, which has well-known ecosystem-engineering effects mediated by both population density and behavior. $D$. cuprea tubes provide both substrate and predation refugia; thus, the abundance and diversity of infauna and epibenthic fauna should both correlate positively with D. cuprea density (Woodin 1978, 1981, Luckenbach 1987, Dudley et al. 1989, Diaz et al. 2003). D. cuprea also actively 'decorates' its tube with foreign material including algal fragments, facilitating an extensive algal canopy in habitats that would otherwise lack stable communities of attached macroalgae (Thomsen \& McGlathery 2005). Algal canopies positively affect marine communities by providing structural heterogeneity, predation refugia, and shading
(Bertness et al. 1999, Burnaford 2004, Irving \& Connell 2006). D. cuprea's algal attachment behavior is also currently facilitating the invasion of Gracilaria vermiculophylla, a red alga that now represents $90 \%$ of algal biomass in some Northwest Atlantic habitats (Thomsen et al. 2006). Thus, D. cuprea's population density and algal attachment behavior together modify both the physical environment and community composition of many shallow-water marine sedimentary habitats in the Northwest Atlantic.

This study asks 3 questions: (1) Does Diopatra cuprea abundance vary with latitude? (2) Does the extent of algal facilitation vary with latitude-and if so, is this the result of latitudinal differences in the worm's ability to find and retain acceptable algae? (3) Does either pattern correlate with environmental factors? I will show that $D$. cuprea 's role as ecosystem engineer varies over its range as a result of (1) decreased abundance at low latitudes, possibly driven by a suite of environmental factors and/or intense post-recruitment mortality, and (2) decreased algal facilitation at low latitudes, driven by geographic changes in the worm's algal attachment behavior. These geographic patterns likely contribute to large-scale spatial heterogeneity in the ecology of marine sedimentary habitats of the Northwest Atlantic.

\section{MATERIALS AND METHODS}

\section{Diopatra cuprea ecology and engineering mechanisms}

Diopatra cuprea occurs commonly in sheltered intertidal sediments of the Northwest Atlantic, tolerating a range of sediment types from sandy mud to coarse sand and a range of salinities from fully marine to polyhaline conditions near the mouths of tidal estuaries. D. cuprea ranges from Cape Cod to Brazil (Fauchald 1977). Cold winter temperatures likely set the northern limit, given that feeding ceases below $5^{\circ} \mathrm{C}$ and tube maintenance ceases below $1.8^{\circ} \mathrm{C}$ (Mangum \& Cox 1971, Myers 1972, see also Berke et al. 2010). Adult D. cuprea occur as far north as Duxbury, Massachusetts $\left(42.05^{\circ} \mathrm{N}\right.$, just north of Cape Cod), but this population does not experience annual recruitment, putting the northern limit for successful reproduction somewhere between Barnstable Harbor and Duxbury (S. Berke pers. obs., D. Wethey \& S. Woodin pers. comm.). D. cuprea is most abundant near the mean low water line, only sparsely extending to the shallow subtidal and the high intertidal 
(Barwis 1985, Peckol \& Baxter 1986, Skoog et al. 1994). The worm builds large tubes ( 1 cm diameter) that penetrate $\geq 1 \mathrm{~m}$ into the sediment and rise several centimeters above the sediment surface; this emergent portion is called the 'tube cap'.

Diopatra cuprea facilitates macroalgae, epibenthic fauna, and infauna. Like most Diopatra spp., D. cuprea actively attaches algae and other materials to its tube cap. The worm captures drift algae by extending $10 \mathrm{~cm}$ or more from its tube, capturing drift algae with its palps and jaws, maneuvering it into position, and integrating it into the tube wall with a mucous secretion (Myers 1972). Algae thus attached form an extensive canopy in habitats that would otherwise feature drift algae but little or no attached macroalgae. Thus, D. cuprea behaviorally mediates the establishment of algal canopies (see my Fig. 1; Thomsen \& McGlathery 2005, S. Berke pers. obs.). D. cuprea feeds on attached algae, and on the numerous small invertebrates attracted to the complex tube structure (Mangum et al. 1968, Berke \& Woodin 2008). The tube thus also provides substrate for smaller fauna, including small crustaceans, polychaetes, flatworms, ophiuroids, and some hardsubstrate organisms such as ascidians and barnacles that otherwise would not occur in sedimentary habitats (Dudley et al. 1989, pers. obs.). By contributing structural complexity, attached algae further facilitate the abundance and richness of the tube cap epifauna (Thomsen et al. 2010).

Diopatra cuprea also facilitates infauna by excluding benthic predators. The strength of this effect partly depends on the number of tubes in a single 'clump' (defined as a $0.01 \mathrm{~m}^{2}$ area by Woodin 1978). Woodin (1981) experimentally identified a threshold density of 6 per clump needed to facilitate infauna (for both real tubes and undecorated model tubes made of drinking straws), but densities between 1 and 6 were not tested. D. cuprea clump density is strongly correlated to mean abundance across sites (worms per $0.01 \mathrm{~m}^{2}=0.33+1.68 \log$ (worms per $\left.0.25 \mathrm{~m}^{2}\right), \mathrm{R}^{2}=0.88, \mathrm{p}<0.0001$, see Fig. $\mathrm{S} 1$ in the supplement at www.int-res.com/articles/suppl/m447p001_ supp.pdf), so the extent to which $D$. cuprea modify infaunal communities is a positive function of overall abundance. Even single $D$. cuprea tubes have been shown to enhance the richness and abundance of benthic fauna provided that algae are attached (Thomsen et al. 2010) (physically similar single tubes of a terebellid polychaete have also been shown to facilitate benthic fauna, Callaway 2006). D. cuprea's algal attachment behavior thus directly facilitates algae but also indirectly enhances facilitation of both infauna and epifauna, above and beyond the structural effect of the tube alone (Thomsen et al. 2010). The 2 key components of $D$. cuprea engineering, then, are (1) its abundance and (2) its algal attachment behavior, which interact to physically modify the habitat and alter the community composition of infauna, epifauna, and algae in sheltered mud flats of the Northwest Atlantic.

\section{Observational data}

Abundance patterns. To evaluate geographic patterns in Diopatra cuprea abundance, populations were censused at 38 sites between Duxbury, Massachusetts $\left(42.05^{\circ} \mathrm{N}\right)$, and St. Lucie Inlet, Florida $\left(27.2^{\circ} \mathrm{N}\right)$; methods were similar to those described by Berke et al. (2010). Sampling locations (see Fig. 2, and Table S1 in the supplement) were chosen with an eye to characterizing large-scale latitudinal changes in density; thus, sites were initially chosen to be $\sim 300 \mathrm{~km}$ apart, with finer-scale sampling subsequently targeted near potential breakpoints. Therefore, sites were $\sim 100 \mathrm{~km}$ apart between South Carolina and Florida, because a major shift in $D$. cuprea abundance was identified in that region. Sampling was less frequent between Cape Cod and South Carolina because suitable $D$. cuprea habitat is less common (and also less accessible) throughout much of this region, the major exception being the coastal bays of Virginia, which were sampled more extensively. Furthermore, populations sampled between Cape Cod and South Carolina had similar densities and algal relationships, suggesting no major biogeographic breakpoints in that region. Fine-scale sampling was resumed near the species' northern range endpoint.

Diopatra cuprea populations at each site were quantified by taking 3 or more transects running parallel to the water line during low tide in the mid to low intertidal, near the mean low water mark (the tidal range of $D$. cuprea's maximum abundance). Each transect was sampled by haphazardly dropping a $0.25 \mathrm{~m}^{2}$ quadrat every 5 paces and counting tubes within the quadrat (every tube represents 1 living worm, Mangum et al. 1968). The length of each transect was determined by the topography of the site, covering the entire space available or at least $50 \mathrm{~m}$ whenever possible. $D$. cuprea distributions are typically clumped; to avoid biasing the samples towards areas of maximum density, transects were taken both in areas of maximum density and in areas of low density at each site. Coordinates and summary statistics for each site are given in Table S1 in the supplement. 
To evaluate biogeographic breakpoints in Diopatra cuprea abundance, I conducted a regression tree analysis on mean density versus latitude using the $\mathrm{R}$ package 'rpart' (R Development Core Team 2010, Therneau et al. 2010). Regression trees partition continuous data into branches that minimize the relative error within each branch, but do not provide a significance test (Venables \& Ripley 2002). To assess whether geographic differences in abundance were significant, sites were assigned to 3 regions based on the regression tree analysis, and mean densities were compared using a Kruskal-Wallis test with multiple comparisons (Siegel \& Castellan 1988). Data from Duxbury, Massachusetts, were excluded from the regression tree analysis for abundance because the population there does not experience annual recruitment.

During a return visit to Flagler Beach, Florida, in July 2009, I found that a massive mortality event had occurred since March of that year. To learn whether similar mortality events occurred at other sites in Florida, I re-sampled 2 other sites for which data from spring 2009 existed: Wabasso and the Smithsonian Marine Station at Ft. Pierce. These data were compared to repeated sampling data from East Wye, Virginia, from April 2008 versus September 2008, and for Burton's Bay, Virginia, for April 2008 versus June 2009 (no northern data were available for both spring and summer of 2009). The time points within each site were compared using $t$-tests.

Algal facilitation. At the 14 sites indicated with green circles in Fig. 2, 10 to 30 tube caps were collected (a list of sites, sample sizes, and summary statistics are given in Table S1 in the supplement). Algae were removed from each cap and sorted to the lowest taxonomic level possible, dried overnight at $60^{\circ} \mathrm{C}$, and weighed. For sites outside of Florida, each taxon was dried and weighed separately. Florida algal fragments, however, were so small that taxonomically splitting the sample would have resulted in subsamples of near-zero mass. Thus, all of the algae from each Florida tube were dried and weighed together, and utilization of different species was quantified by counting the number of fragments of each taxon on the tube. A geographic breakpoint was identified with a regression tree analysis for mean total dry weight of algae per tube, which suggested 2 branches separated by a single node. An ANOVA was used to compare the log-transformed mean algal weight for sites in each branch, and residuals were examined for heteroscedasticity. While it was not possible to quantify algal facilitation at every site, the quantitative data were supplemented with photographs and field observations to qualitatively assess whether Diopatra cuprea at other sites attached relatively large or small quantities of algae.

To assess patterns in algal communities, nonmetric multidimensional scaling (MDS) was conducted on a presence-absence matrix for algal taxa at each site (see Table S2 in the supplement) (R package 'vegan', Oksanen et al. 2011, using the Jaccard dissimilarity index). The distributions of algal species richness per tube were also compared across sites.

Environmental parameters. To assess whether Diopatra cuprea abundance correlates with commonly measured environmental parameters, publicly available environmental data were obtained for 11 sites (see Fig. S2 in the supplement): Barnstable Harbor, Massachusetts (Cape Cod Cooperative Extension 2007-2010), Oyster Landing, South Carolina, Debbidue Creek, South Carolina (Smith et al. 1996-2009), Sapelo Island, Georgia (Hurley 1996-2004), Ft Matanzas, Florida (Gleeson 2001-2006), and 6 sites in the Indian River Lagoon, Florida-Sebastian Inlet, Wabasso, Jaycee Park, Gilbert's Bar, Stuart (Indian River Lagoonwatch 1996-2009) and the Smithsonian Marine Station at Ft. Pierce (Smithsonian Marine Science Network 2006-2009). These represent all of the sites for which (1) data are publicly available and (2) D. cuprea abundance is known (see Fig. 2, and Table S1 in the supplement), except for Sapelo Island, Georgia, where D. cuprea populations are qualitatively similar to those elsewhere in Georgia and South Carolina (S. Woodin pers. comm.). Bias in the geographic distribution of sites with environmental data reflects the geographic bias in public data repositories, with greater coverage in Florida than elsewhere. However, the primary goal was to compare the physical environment of sites within versus outside of Florida, making this bias less problematic than it might otherwise be. Other limitations are that the precise depth likely varied between sites, although all are shallow-water estuarine sites, and different date ranges are represented at each site-in particular, the Barnstable Harbor data do not include any winter months (November to March).

Principal component analyses (PCAs) on meancentered annual means and ranges of temperature, salinity, dissolved oxygen (DO), pH, chlorophyll a (chl a) concentration, and turbidity were used to evaluate whether southern sites cluster separately from sites farther north based on environmental parameters alone. However, not all metrics were available at all sites. Thus, 2 separate PCAs were conducted: (1) the annual mean and range of temperature, salinity, DO, and $\mathrm{pH}$ at all sites, and (2) these 
parameters plus the annual mean and range in chl a and turbidity at the subset of 6 sites for which chl $a$ and turbidity were available (listed in the legend of Fig. 5). To assess whether either Diopatra cuprea abundance or algal biomass correlate to the multivariate combination of environmental parameters, log-transformed abundance and algal biomass were each regressed against the scores of the first 2 PCA axes.

The PCA analysis was supplemented with regression modeling for Diopatra cuprea abundance (for the 10 sites with both abundance and environmental data, see legend of Table S6 in the supplement) as well as the biomass of attached algae facilitated (for the 8 sites with both algal and environmental data, see legend of Table S7 in the supplement). Predictors tested included the annual mean and range of temperature, salinity, $\mathrm{DO}$, and $\mathrm{pH}$. Multiple regressions were selected using an exhaustive subsetting method to find the combination of parameters yielding the most informative model based on the Bayesian information criterion (BIC, similar to the Akaike information criterion), using the regsubsets function in the $\mathrm{R}$ package 'leaps' (Lumley 2009, R Development Core Team 2010). Linear regressions are appropriate here because there is no evidence that the abundance shows a curvilinear or humped shape for any environmental parameter (see Fig. S4 in the supplement). Ordinary least squares linear regressions for each predictor were also computed. For all regressions, assumptions of homoscedasticity and normality were verified by examining the residuals and $\mathrm{Q}-\mathrm{Q}$ plots.

\section{Algal facilitation experiments}

Southern Diopatra cuprea might attach less algae (1) if drift algae are less available at Florida sites (unlikely though this seems, given the diversity and abundance of drift algae in the Indian River Lagoon, Virnstein \& Carbonara 1985), (2) if acceptable algal species are less available at Florida sites, e.g. because drift algae are unpalatable due to degradation or induced chemical defenses in Florida (this, too, seems unlikely given that $D$. cuprea readily decorates with the chemically defended Dictyota menstrualis in Georgia, J. Stachowicz pers. comm.), or (3) if attached algae are not retained on the tube, e.g. because intertidal algae degrade rapidly in the subtropics or because herbivory is more intense in the subtropics (Floeter et al. 2005). If drift algae are simply less available in Florida, then worms offered abundant algae should readily attach it. If the algae available in Florida are unpalatable to D. cuprea, then worms offered acceptable species should attach it at similar rates in both places. Finally, if herbivory or rapid degradation prevent attached algae from being retained, then worms offered algae in the laboratory should readily attach and retain it.

To test these hypotheses, I conducted a series of field and laboratory experiments at the Smithsonian Marine Station at Ft. Pierce, Florida (SMSFP) $\left(27.548^{\circ} \mathrm{N}, 80.306^{\circ} \mathrm{W}\right)$, and at the Virginia Institute of Marine Science Eastern Shore Laboratory in Wachapreague, Virginia (ESL) $\left(37.620^{\circ} \mathrm{N}, 75.668^{\circ} \mathrm{W}\right)$, in which worms forced to rebuild their tube caps were offered various algae as decoration. The SMSFP site is a sheltered muddy sand flat in the Indian River Lagoon immediately south of Ft. Pierce inlet. The site features patchy seagrasses (Halodule spp. in the upper intertidal, Thalassia just below the low-tide line) and red mangroves. The ESL site, known locally as 'Worm Flat', is a large sheltered mud flat in Burton's Bay, part of the Virginia coastal bay system. The flat is physically dominated by Diopatra cuprea tubes, and adjoins Spartina alterniflora marsh as well as oyster reefs.

In each field experiment, algae were tied to $10 \mathrm{~cm}$ aluminum stakes that were driven into the sediment immediately next to a Diopatra cuprea tube. The existing tube cap was then severed, forcing the worm to build a new cap, which occurred within $24 \mathrm{~h}$ (worms either attached the free edges of algae directly to the tube, or attached fragments of algae which they cut off using their jaws, just as they do when encountering drift algae in the field). In every case, the amount of algae offered exceeded the amount a single worm could likely use. Field and laboratory experiments were compared using Fisher's exact test on the number of worms attaching any algae at all for each experiment. Pairwise comparisons were drawn using a Bonferroni correction for Florida versus Virginia field experiments, Florida field versus laboratory experiments, and Virginia field versus Florida laboratory experiments.

(1) Facilitation of common drift algae. Worms in Florida and in Virginia were simultaneously offered equal masses of the 3 algal species most commonly found as drift algae at each site $(0.5 \pm 0.1 \mathrm{~g}$ of each). In Florida $(\mathrm{n}=24)$, these were the branching red algae Acanthophora spicifera and Hypnea musciformis, and the filamentous green alga Caulerpa fastigiata, which is occasionally found on Florida tubes. In Virginia ( $\mathrm{n}=14$ ), these were the green sheet-forming alga Ulva lactuca and the branching red algae Gracilaria tikvahiae and G. vermiculo- 
phylla. The latter is an invasive species that now represents most algal biomass at the site (Thomsen et al. 2006).

(2) Facilitation of 'acceptable' algae. Worms in Florida and Virginia were offered Ulva lactuca alone to compare the frequency at which it is attached at each site. Additionally, Florida worms were offered Gracilaria tikvahiae alone as a further point of comparison to Virginia field observations, given that Virginia Diopatra cuprea tubes nearly always have Gracilaria spp. attached. To avoid problems of degradation and heat-induced defenses in Florida, these Florida trials used algae cultured at the Harbor Branch Oceanographic Institute Algal Culture Facility. These specimens were raised in laboratory conditions, and were not exposed to intertidal stresses until the day of the experiment.

(3) Algal facilitation in the laboratory. Laboratory experiments were conducted in Florida to determine if a controlled, herbivore-free environment would allow greater algal facilitation than observed in the field. Worms in their natural tubes were 'potted' in glass test tubes $(13 \times 100 \mathrm{~mm})$ with sediment from the field site. The test tubes were held upright in a rack made of plastic grating nested in a flow-through seawater tank. The grating was flush with the tops of the tubes and supported $5 \mathrm{~cm}$ diameter plastic dishes topping each tube; each dish had a $1.5 \mathrm{~cm}$ hole in the center to accommodate the test tube and contained sediment from the collection site. Each worm could thus build a new tube cap up through the hole using the sediment provided (see Brenchley 1976, her Fig. 1). Algae were secured to the edge of each dish with clothespins. In one experiment, worms were offered either field-collected Hypnea musciformis $(\mathrm{n}=10)$ or cultured Ulva lactuca (known to be readily used at northern sites, $\mathrm{n}=10$ ). In a second experiment, worms were offered only cultured U. lactuca $(\mathrm{n}=23)$. In both experiments, cultured U. lactuca was used to avoid degradation and environmentally induced defenses.

\section{RESULTS}

\section{Observational data}

Abundance. Diopatra cuprea abundance is significantly lower in Florida compared to sites further north (Figs. 1 \& 2). Regression tree analysis partitioned the abundance data into 3 regions with the first node at $30.9^{\circ} \mathrm{N}$ latitude, the midpoint between sites at Jekyll Island, Georgia $\left(31.02^{\circ} \mathrm{N}\right)$ and Elliot's Bluff, Georgia $\left(30.85^{\circ} \mathrm{N}\right)$, just north of the Florida-
Georgia border (Fig. 2, relative error 0.67, mean squared error $[\mathrm{MSE}]=1635.7$ ). The second node was near $34^{\circ} \mathrm{N}$, between the North Carolina and South Carolina sites (relative error 0.64, MSE $=17.9$ ); however, the relative error of this node is only slightly smaller than that of the first node, indicating that most of the variance in the data is partitioned at the first node. Kruskal-Wallis tests indicated that $D$. cuprea mean abundance is significantly lower in Florida compared to each of the other regions (overall $\chi_{2}^{2}=21.43, \mathrm{p}<0.0001$, Florida vs. Georgia-toSouth Carolina $\mathrm{p}=0.002$, Florida vs. North Carolinato-Massachusetts $\mathrm{p}=0.0001$ ). The Georgia-to-South Carolina region was not significantly different from the North Carolina-to-Massachusetts region, confirming that the only geographic breakpoint with a significant effect size is at $30.9^{\circ} \mathrm{N}$.

Between March and July 2009, Diopatra cuprea populations plummeted at all 3 Florida sites where repeated sampling occurred (Fig. 3, Table S4 in the supplement). Similar mortality events were not observed at sites in Virginia. The most extreme mortality was at Flagler Beach-while D. cuprea was common there in March, in July I found only 2 individual worms, despite extensively searching the site. None of the 3 Florida populations were obviously dominated by new recruits in March (new recruits have tubes $<5 \mathrm{~mm}$ diameter, but I have only rarely seen this size-class in Florida). Thus, the individuals that died were not likely to have been newly settled juveniles, but may have been anywhere from several months to over a year in age.

Algal facilitation. Diopatra cuprea outside of Florida attaches large quantities of algae, while $D$. cuprea in Florida attaches only minute fragments of algae or none at all (Figs. 1 \& 2). Regression tree analysis indicated a single node for the algal biomass data, coinciding with the abundance node at $30.9^{\circ} \mathrm{N}$. The mean mass of algae per $D$. cuprea tube was significantly smaller at sites south versus north of this node (ANOVA $F_{1,13}=48.76, \mathrm{p}<0.0001$ ). This pattern was qualitatively consistent across sites where algae were not sampled, based on photographs and field notes (Fig. 2, Table S1 in the supplement). More details about algal taxa identified are provided in the supplement (Tables S2 \& S3). Taken together, the quantitative and qualitative data agree that $D$. cuprea facilitates algae throughout most of the study range. Both types of data indicate a similar biogeographic breakpoint in algal facilitation (although the qualitative data suggest a break at Nassau Sound at $30.5^{\circ} \mathrm{N}$, which is slightly south of that suggested by the regression tree, the regression tree breakpoint at 

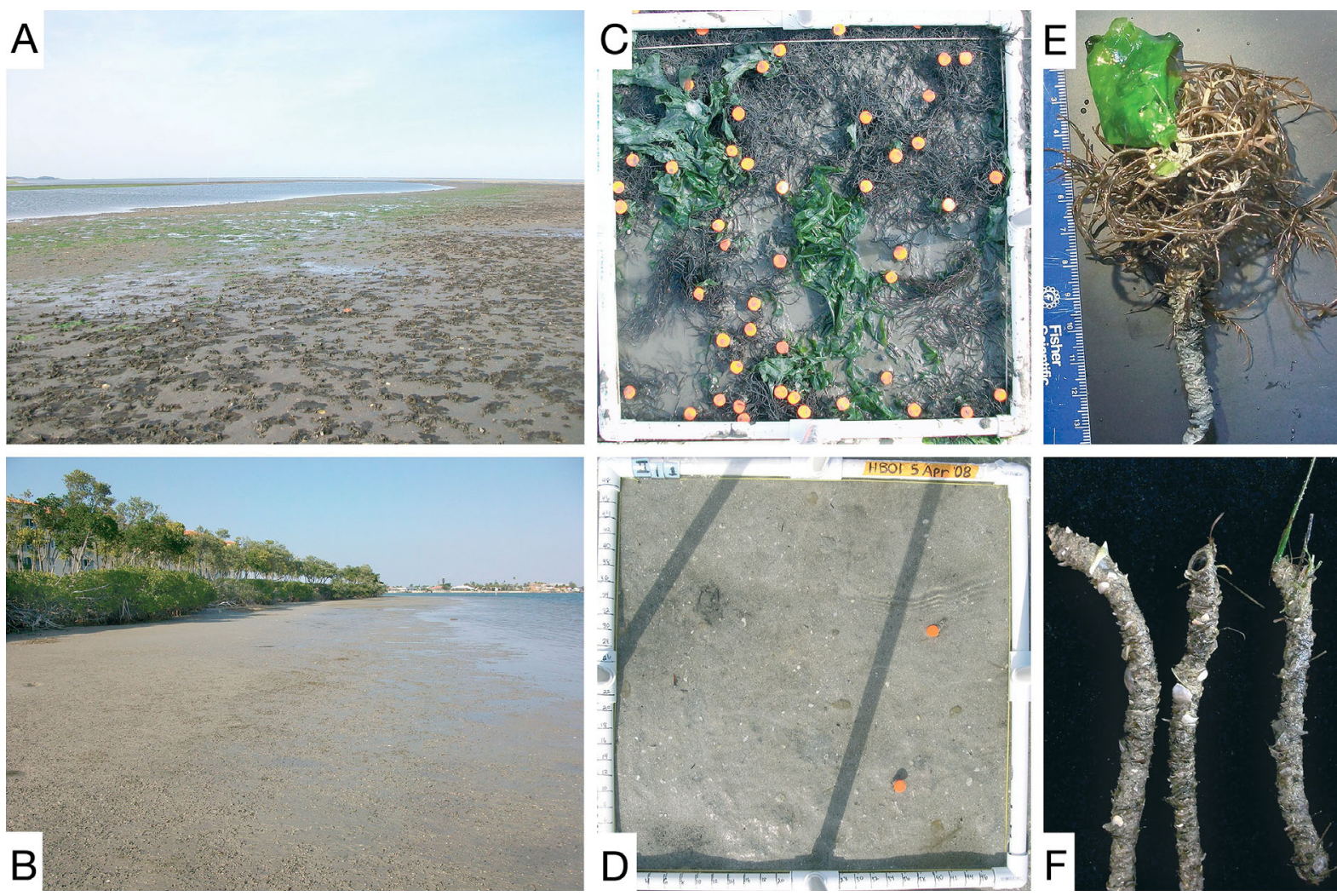

Fig. 1. Diopatra cuprea. (A) The experimental site in Burton's Bay, Virginia, showing an extensive canopy of red and green algae attached to D. cuprea tubes. (B) The experimental site in the Indian River Lagoon, Florida. Seagrass (primarily Halodule wrightii) creates roughness in the foreground. Note the lack of attached macroalgae-although drift algae are common throughout the region, D. cuprea do not attach it to create algal canopies. (C,D) Quadrats $\left(0.25 \mathrm{~m}^{2}\right)$ in $(\mathrm{C})$ Virginia and (D) Florida, with round pins marking each D. cuprea; the algae in (C), primarily Gracilaria vermiculophylla and Ulva sp., are attached to the numerous D. cuprea tubes. (E,F) Excavated tubes from (E) Virginia and (F) Florida. The Virginia tube has

copious G. vermiculophylla and Ulva sp. attached, while the Florida tubes have a few blades of seagrass, but no algae

$30.9^{\circ} \mathrm{N}$ is merely the midpoint between the 2 sites on either side of the break, so both analyses are consistent).

The MDS analysis showed that sites in Florida cluster separately and more tightly in the community ordination space compared to sites outside of Florida (Fig. 4A). Florida Diopatra cuprea also supported fewer species of algae than D. cuprea elsewhere (Fig. 4C).

Environmental parameters. PCA analyses indicated that northern sites (with abundant Diopatra cuprea) cluster separately from Florida sites (with sparse D. cuprea) (Fig. 5). In both analyses, sites separated most strongly along the axis reflecting mean $\mathrm{pH}$ and salinity. The PCA analysis for the mean and range of temperature, salinity, $\mathrm{DO}$, and $\mathrm{pH}$ further suggested a possible role for the annual range of $\mathrm{pH}$, while the PCA that additionally included chl $a$ and turbidity also indicated that the annual range of chl a concentration is a key factor distinguishing the sites (Fig. 5, Table S5 in the supplement). However, this may be biased by the very large range of chl a at the
Smithsonian Marine Station (Fig. S2 in the supplement). The position of Barnstable Harbor, Massachusetts, should also be interpreted cautiously, because this site did not have winter data. Both abundance and algal biomass were marginally correlated with the first axis of the environmental PCA (Fig. S3 in the supplement, abundance $=2.15-0.92 x, \mathrm{R}^{2}=0.32, \mathrm{p}=$ 0.09 ; algal biomass $=2.16-1.06 x, \mathrm{R}^{2}=0.44, \mathrm{p}=0.07$ ) Including the second PCA axis worsened both regressions.

Exhaustive regression subsetting indicated that the best multivariate model for Diopatra cuprea abundance included all parameters except for mean $\mathrm{pH}$ (which is collinear with temperature) (parameters given in Table S6 in the supplement, BIC $=-62.2$, adjusted $\mathrm{R}^{2}=0.998$ ). The best multivariate model for attached algal biomass included all parameters except for mean salinity and mean DO (parameters given in Table S7 in the supplement, $\mathrm{BIC}=-49.76$, adjusted $\mathrm{R}^{2}=0.998$ ). Raw data are shown in Figs. S3 \& S4 in the supplement. 


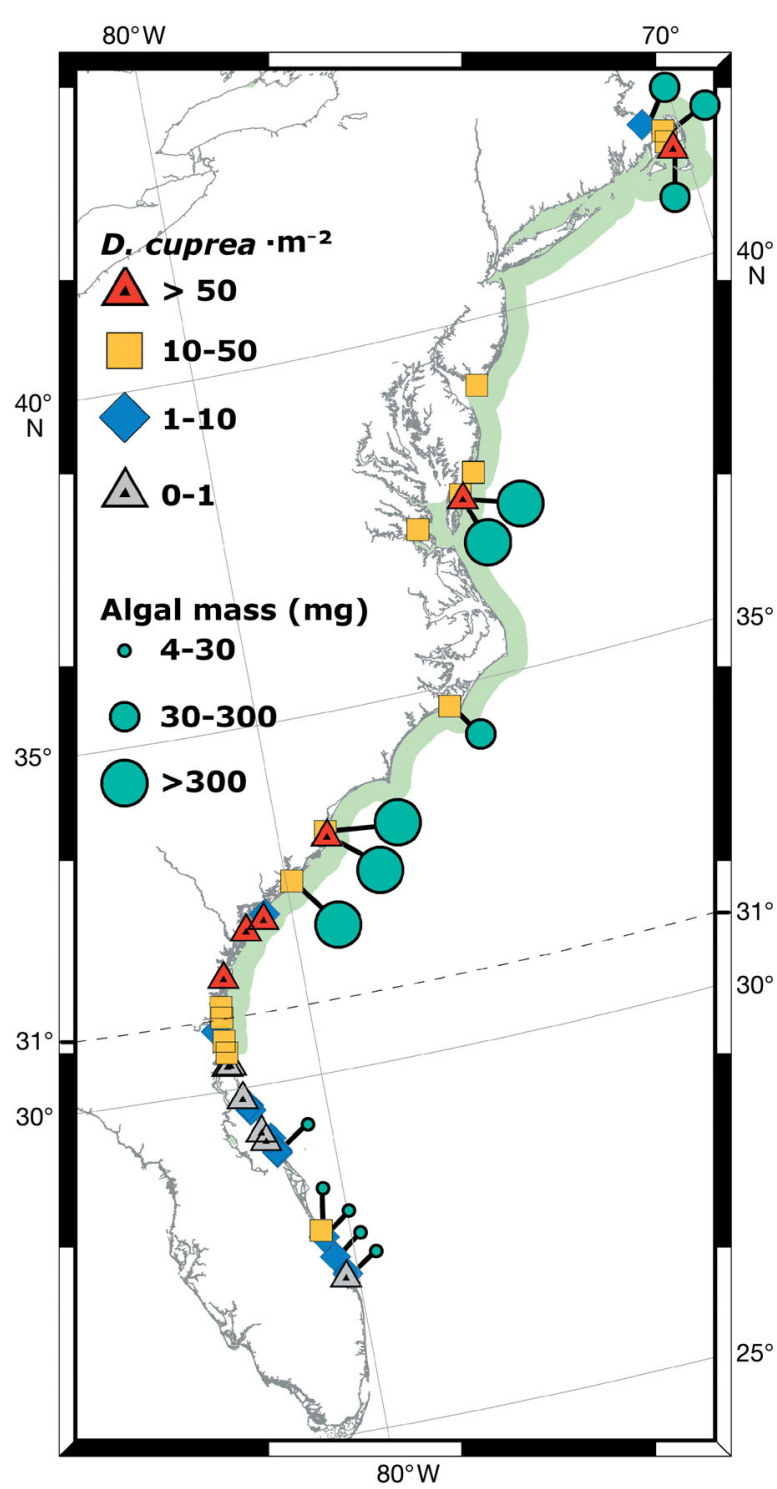

Fig. 2. Diopatra cuprea abundance and facilitation of macroalgae by $D$. cuprea, in the eastern United States. (Triangle, diamond, and square symbols) Mean abundance per $\mathrm{m}^{2}$. (Circles) Mean dry weight of algae per tube (mg). The dashed line indicates the node suggested by regression tree analysis on $D$. cuprea abundance and algal biomass facilitated, see 'Materials and methods' for details. Light green shading indicates the region in which $D$. cuprea attaches large quantities of algae, based on qualitative assessments. A complete list of sites with coordinates and summary statistics for abundance and algal mass is provided in Table S1 in the supplement at www.int-res.com/articles/suppl/m447p001_ supp.pdf

\section{Experimental results}

All worms in the Virginia field experiments attached algae to their tubes within $24 \mathrm{~h}$ (Table 1). Of Virginia worms offered a choice of 3 algae (Gracilaria vermiculophylla, G. tikvahiae, Ulva lactuca), 100\% used at least 1 species, and overall the species were used equally. Of Virginia worms offered U. lactuca alone, $100 \%$ attached it while $60 \%$ also added $G$. vermiculophylla, which they obtained from the surrounding habitat. The Florida field experiments showed strikingly different patterns (Table 1): only $48 \%$ of Florida worms given a 3-way choice (Acanthophora spicifera, Hypnea musciformis, Caulerpa fastigiata) used any algae at all, and those that did used only small fragments. Of Florida worms offered G. tikvahiae or U. lactuca alone, only $40 \%$ used G. tikvahiae and $20 \%$ used U. lactuca (Table 1). Florida worms also attached algae at comparatively low rates in the laboratory, with only $60 \%$ adding $H$. musciformis and $36 \%$ adding $U$. lactuca (Table 1). In the second, larger $U$. lactuca-only laboratory experiment, again only $41 \%$ of worms attached the algae. Overall, Florida worms added algae significantly less frequently than Virginia worms (Fig. 6, Fisher's exact test $\mathrm{p}<0.0001$, Bonferroni corrected).

The different frequencies of algal attachment in Virginia versus Florida were striking, but even more striking were qualitative differences in attachment between the 2 populations. In Virginia, algae were extensively incorporated into the tube, woven into the tube walls with multiple attachment points to form robust connections (as seen in Fig. 1E). From my observations of Diopatra cuprea throughout the eastern United States, this is typical of worms between Cape Cod and Georgia. In Florida, however, algae were only tenuously attached to tubes, with only one or a few points of attachment to the outer surface of the tube, and algae were only rarely woven into the tube wall.

\section{DISCUSSION}

Diopatra cuprea influences marine sedimentary habitats as a function of both abundance and behavior: the physical structure of the tube stabilizes sediment at depth, enhances surface scour, and enhances the abundance/richness of benthic fauna (Woodin 1981, Luckenbach 1986, Thomsen et al. 2010) —all effects that increase with population abundance. The worm's behavior additionally facilitates macroalgal communities, often creating extensive and persistent algal canopies in habitats that would otherwise lack attached algae, and enhancing the tubes' structural effects on infauna and epifauna (Thomsen \& McGlathery 2005, Thomsen et al. 2010).

This study shows a strong latitudinal pattern in both Diopatra cuprea density and algal facilitation in 
Fig. 3. Diopatra cuprea. Post-recruitment mortality may play a role in limiting Florida populations. In Florida, 3 sites experienced dramatic declines in $D$. cuprea abundance from spring to summer of 2009. Similar changes were not observed at the East Wye Virginia site from February to September of the previous year, or at the experimental site ('Worm Flat') at the Virginia Institute of Marine Science Eastern Shore Laboratory (ESL) from spring of 2008 to summer of the following year. East Wye has sparser populations than the ESL site, most likely because East Wye is sandier and experiences greater wave energy. $\mathrm{p}$-values are for $t$-tests at each site, temporal differences in Virginia were not significant. Boxes: 1st and 3rd quartiles; whiskers: largest/smallest data values (or 1.5 times the inter-quartile range when outliers are present, indicated by open circles); Notches: 95\% about the medians (thick horizontal lines)

the Northwest Atlantic (Figs. 1 \& 2). D. cuprea populations are clearly divided into 2 groups with a breakpoint near the Florida-Georgia border. North of this breakpoint (from Massachusetts to Georgia), D. cuprea are abundant and extensively facilitate algae. South of this breakpoint (in Florida), D. cuprea are sparse and facilitate little algae. As a result, attached algal canopies in Florida sedimentary habitats are rare or nonexistent (Figs. 1, $2 \& 4$ )

Florida Diopatra cuprea populations are so sparse that infaunal diversity and abundance are unlikely to be elevated in Florida $D$. cuprea habitats, consistent with Ban \& Nelson's (1987) finding for D. cuprea near Sebastian Inlet. Clumps dense enough to provide predation refugia are seldom observed (see Woodin 1978), and the absence of attached algae would predict that single tubes have little to no effect on benthic fauna (see Thomsen et al. 2010).

One obvious hypothesis not considered here is that Diopatra cuprea in Florida is a distinct species. However, mitochondrial COI (cytochrome c oxidase subunit I) data collected as part of a phylogeographic analysis for $D$. cuprea indicate that species-level genetic differences cannot account for the geographic patterns presented here (T. Bell, S. Berke \& E. Sotka unpubl. data). The biogeographic pattern could of course reflect genetic structure among $D$.

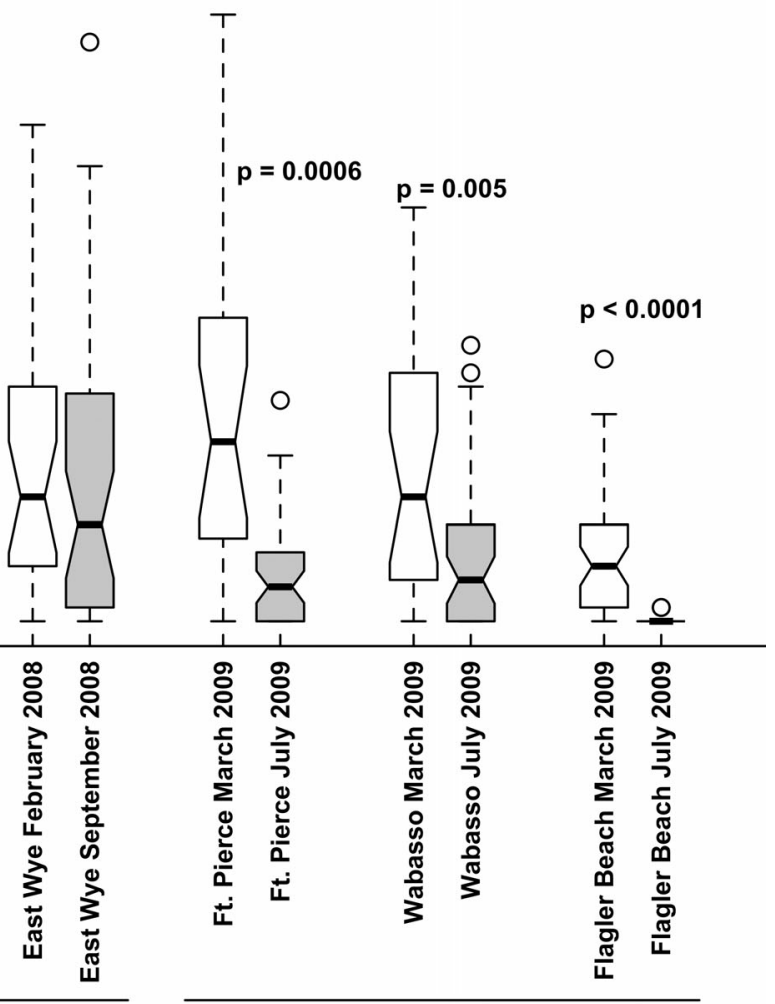

Virginia

Florida

cuprea populations, and future work with more sensitive markers would be fruitful. Regardless of whether the geographic patterns reflect local adaptation or phenotype plasticity, however, understanding the mechanisms that limit population size and alter the cost-benefit tradeoffs of algal attachment behavior is an important goal.

The experimental data rule out several possible mechanisms for latitudinal changes in algal facilitation. The algal facilitation pattern is clearly not driven by latitudinal changes in algal availability, acceptability, or retainability. When algal availability and type are manipulated, the behavior of individuals from Florida is strikingly and significantly different from the Virginia population (Fig. 6). If drift algae are unavailable or unretainable in Florida, then worms offered algae ad libitum in the laboratory should decorate extensively - this was not observed. If preferred species of algae are not available in Florida, then Florida worms should readily attach species commonly used in the north-this was not observed. Finally, the possibility that Florida algae are unacceptable due to degradation or induced chemical defenses can be ruled out given that (1) the Florida experiments offering Ulva lactuca and Gracilaria tikvahiae used algae grown in culture facilities, thus any inducible defenses unique to sub- 

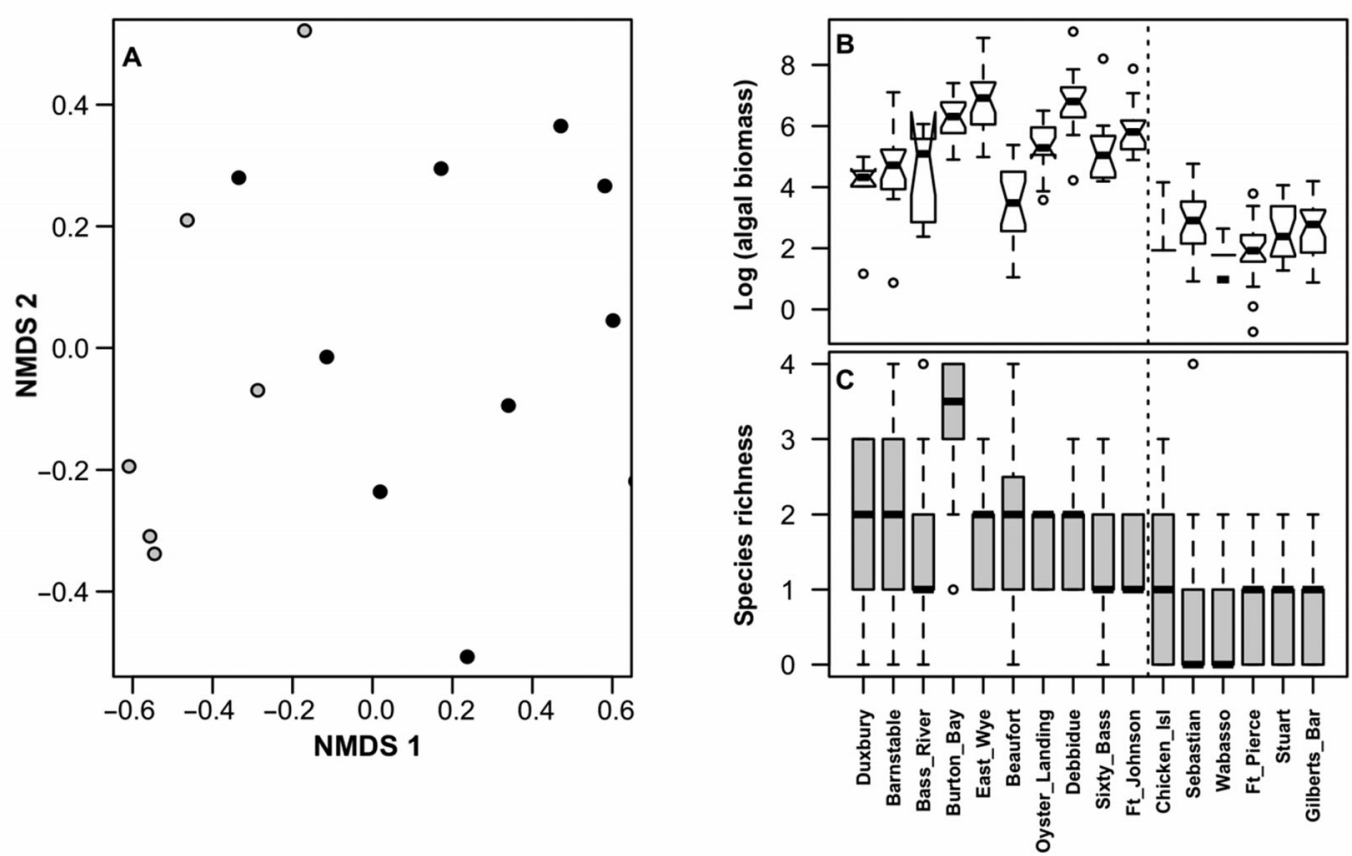

Fig. 4. Changes in the algal community, with latitude. (A) Community multidimensional scaling (MDS) on a presence-absence matrix (Table S2 in the supplement at www.int-res.com/articles/suppl/m447p001_supp.pdf) of algal taxa at each site. Stress = 12.08. (o) Sites in Florida; (•) sites outside of Florida. The 2 clusters are virtually non-overlapping in ordination space. (B) Distribution of algal biomass (log scale) per tube for sites from north (left) to south (right), as also shown in Fig. 2. The dotted line separates the 2 branches identified by regression tree analysis on algal biomass. (C) Distribution of species richness per tube. Florida Dictyota cuprea facilitates fewer algal species than those at more northern sites. Boxplots are as described for Fig. 3

tropical intertidal conditions would most likely not have been expressed in these samples (especially for the laboratory experiments which maintained algae in laboratory conditions throughout), and (2) Diopatra cuprea populations in Georgia readily attach Dictyota menstrualis (J. Stachowicz pers. comm.), despite its well-known chemical defenses (e.g. Stachowicz \& Hay 1999).

The environmental data suggest that Diopatra cuprea abundance and algal facilitation are each correlated to a suite of environmental factors, including chl $a, \mathrm{pH}$, salinity, and temperature. It is possible that Florida populations are less abundant due to environmental stress from one or more of these parameters; further experimental studies of $D$. cuprea physical tolerances would help to further evaluate this hypothesis. A causal link between environmental parameters and the lack of algal attachment is more difficult to envision -in particular, attached algae should provide shading and a ready food supply, which ought to ameliorate environmental conditions. Of course, the abundance pattern and the algal attachment pattern could well have different causes.

The breakpoint identified by regression trees for both abundance and algal attachment strikingly cooccurs with a major shift in coastal geology, from extensive marshes with substantial terrigenous input to lagoonal systems with less siliciclastic content (Milliman et al. 1972) and a smaller tidal range. Some correlate of these different geological backgrounds might influence nutrient dynamics and/or trophic webs to affect Diopatra cuprea abundance and/or behavior at southern latitudes, which would be consistent with the importance of chl $a$ in the PCA analysis. Changing sedimentary characteristics could also change the tubes' physical properties, perhaps interfering with algal attachment. The geographic breakpoint also falls just north of the northern limit for mangrove species, but mangroves are limited by the frequency of hard freezes (Stuart et al. 2007), which seems unlikely to influence $D$. cuprea abundance or behavior.

In many ways, biological interactions seem more plausible mechanisms than physical factors alone. In particular, increased predation due to the latitudinal gradient in predation intensity (Bertness et al. 1981, Menge \& Lubchenco 1981) or due to longer tidal immersion times in Florida may limit Diopatra cuprea abundance. Similarly, increased herbivory in Florida (Menge \& Lubchenco 1981, Floeter et al. 2005) could alter the selective benefits surrounding algal attachment, leading to local adaptation. While it is not clear 

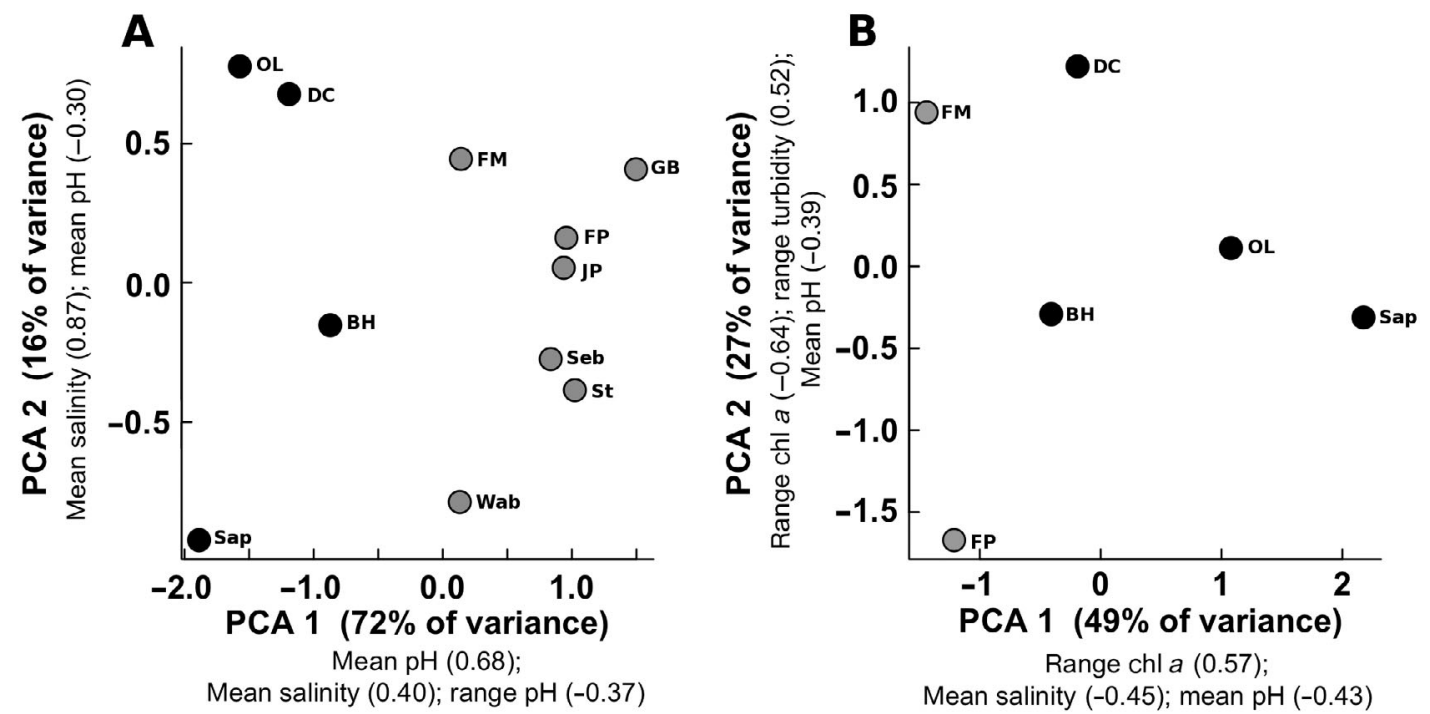

Fig. 5. Principal component analyses (PCAs) for 2 sets of environmental parameters: (A) the annual mean and annual range in salinity, dissolved oxygen, and $\mathrm{pH}$, and (B) the annual mean and annual range in salinity, dissolved oxygen, $\mathrm{pH}$, chl $a$, tur-

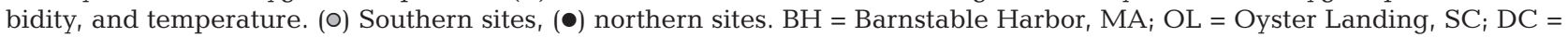
Debbidue Creek, SC; Sap = Sapelo Island, GA; FM = Ft. Matanzas, FL; Seb = Sebastian Inlet, FL; Wab = Wabasso, FL; JP = Jaycee Park, FL; FP = Smithsonian Marine Station at Ft. Pierce, FL; GB = Gilbert's Bar, FL; St = Stuart, FL. In both analyses, sites strongly differentiate along Axis 1. Primary loadings are indicated in the axis labels; complete axis loadings are shown in Table S5 in the supplement at www.int-res.com/articles/suppl/m447p001_supp.pdf

what caused the mortality events observed in Florida (Fig. 3), these events do suggest that high mortality may be one factor limiting population growth for Florida D. cuprea, in contrast to populations farther north (Fig. 3, see also Peckol \& Baxter 1986). Clearly, we need a deeper understanding of $D$. cuprea autecology, the function of its tube and decoration, and its interactions with other organisms to fully understand the observed geographic patterns.

Diopatra cuprea is currently facilitating the invasion of the western Pacific red alga Gracilaria vermiculophylla in much of its range (Thomsen et al. 2006); in Virginia's coastal bays, G. vermiculophylla now represents up to $90 \%$ of algal biomass, most of it secured to D. cuprea tubes. In 2009, I found intertidal G. vermiculophylla from Virginia through southern Georgia, but not in Florida (although it may occur subtidally as far south as St. Augustine, E. Sotka pers. comm.). While G. vermiculophylla is an adept invader in its own right, D. cuprea's failure to facilitate algae in Florida may be one factor slowing the alga's spread in shallow Florida waters. Understanding how invasive species interact with geographically variable ecosystem engineers across the engineer's range is particularly fascinating and warrants further study.
In summary, biogeographic patterns in Diopatra cuprea abundance and algal facilitation contribute to large-scale spatial heterogeneity of Northwestern Atlantic sedimentary habitats. The mechanisms driving these patterns remain unclear, and future stud-

Table 1. Diopatra cuprea. Percentage of worms attaching algae in field and laboratory experiments. Numbers in parentheses indicate the mean dry mass $(\mathrm{mg}) \pm \mathrm{SE}$ of algae attached. Ulva lactuca and Gracilaria spp. are commonly attached by D. cuprea, and widely occur as drift algae in Virginia. Hypnea musciformis, Caulerpa fastigiata, and Acanthophora spicifera are commonly occurring drift algae in Florida, but are seldom found attached to tubes in the field

\begin{tabular}{|c|c|c|c|}
\hline \multicolumn{2}{|l|}{ Field experiments } & \multicolumn{2}{|c|}{ Laboratory experiments } \\
\hline Florida A & & $\mathbf{A}$ & \\
\hline H. musciformis & $26(1.9 \pm 3.9)$ & H. musciformis & 60 \\
\hline C. fastigiata & $39(0.8 \pm 1.6)$ & U. lactuca & 36 \\
\hline A. spicifera & 0 & & \\
\hline Any & $48(2.7 \pm 4.7)$ & & \\
\hline Florida B & & B & \\
\hline U. lactuca & $20(12.0 \pm 22.5)$ & U. lactuca & 41 \\
\hline G. tikvahiae & $40(9.1 \pm 11.7)$ & & \\
\hline Any & 40 & & \\
\hline \multicolumn{4}{|l|}{ Virginia A } \\
\hline U. lactuca & $64(77.4 \pm 136.0)$ & & \\
\hline G. tikvahiae & $50(5.6 \pm 11.2)$ & & \\
\hline G. vermiculophylla & $71(17.0 \pm 22.3)$ & & \\
\hline Any & $100(100.1 \pm 136.2)$ & & \\
\hline \multicolumn{4}{|l|}{ Virginia B } \\
\hline U. lactuca & 100 & & \\
\hline
\end{tabular}




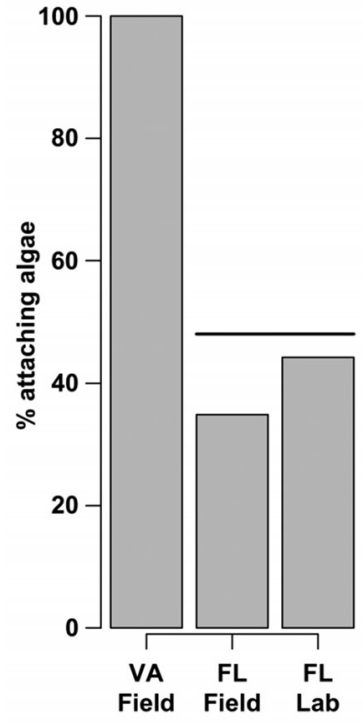

Fig. 6. Diopatra cuprea. Florida (FL) worms attach algae far less frequently than Virginia (VA) worms ( $p<0.0001$ Fisher's exact tests with Bonferroni corrections). Bars show the percentage of individuals adding any algae in field and laboratory experiments for Virginia and Florida (see Table 1); black horizontal line $=$ no significant difference

ies focusing on the factors influencing $D$. cuprea success and behavior are needed. This case provides an intriguing example of an ecosystem-engineering organism having highly variable engineering effects throughout its range due to variability in both density and behavior. Understanding the extent to which ecosystem-engineering effects map onto species ranges - and the mechanisms underlying such spatial heterogeneity-is an important component of understanding how engineering processes interact with larger-scale ecogeographic patterns.

Acknowledgements. S. Woodin generously helped census worms in the southeast, despite great muddiness, and also commented extensively on the manuscript-I thank her for many years of enlightenment and tea. I thank R. Osman, D. Jablonski and several anonymous reviewers for valuable comments on the manuscript, and S. Kidwell and M. Luckenbach for insightful conversations. Logistical support and access to facilities and field sites were facilitated by $M$. Luckenbach and the staff of the VIMS Eastern Shore Laboratory and by V. Paul and the staff of the Smithsonian Marine Station at Ft. Pierce. I thank S. Fate, S. Reed, H. Reichardt, R. Ritson-Williams, R. Osman, R. Whitlatch, M. Luckenbach and V. Cruz for their cheerful field assistance. Finally, I thank P. Kenny and J. Craft for collecting worm tubes, J. Reitsma for help accessing water quality data, and D. Mitchell for computing support. I was supported by a Smithsonian Environmental Research Center Marine Science Network Fellowship and NOAA (NA04NOS4780264 to S. Woodin) while conducting this research, and by the National Science Foundation (EAR-0922156 to D. Jablonski) while writing the manuscript. This is contribution No. 872 from the Smithsonian Marine Station at Fort Pierce.

\section{LITERATURE CITED}

Badano EI, Cavieres LA (2006) Ecosystem engineering across ecosystems: do engineer species sharing common features have generalized or idiosyncratic effects on species diversity? J Biogeogr 33:304-313

Ban SM, Nelson WG (1987) Role of Diopatra cuprea Bosc (Polychaeta: Onuphidae) tubes in structuring a subtropical infaunal community. Bull Mar Sci 40:11-21

Barwis JH (1985) Tubes of the modern polychaete Diopatra cuprea as current velocity indicators and as analogs for Skolithos-Monocraterion. In: Curran HA (ed) Biogenic structures: their use in interpreting depositional environments. Spec Publ 35. Society of Economic Paleontologists and Mineralogists, Tulsa, OK, p 225-235

$>$ Bell JD, Westoby M (1986) Variation in seagrass height and density over a wide spatial scale: effects on common fish and decapods. J Exp Mar Biol Ecol 104:275-295

Berke SK, Woodin SA (2008) Tube decoration may not be cryptic for Diopatra cuprea (Polychaeta: Onuphidae). Biol Bull 214:50-56

Berke SK, Mahon AR, Lima FP, Halanych KM, Wethey DS, Woodin SA (2010) Range shifts and species diversity in marine ecosystem engineers: patterns and predictions for European sedimentary habitats. Glob Ecol Biogeogr 19:223-232

> Bertness MD, Garrity SD, Levings SC (1981) Predation pressure and gastropod foraging: a tropical-temperate comparison. Evolution 35:995-1007

Bertness MD, Leonard GH, Levine JM, Schmidt PR, Ingraham AO (1999) Testing the relative contribution of positive and negative interactions in rocky intertidal communities. Ecology 80:2711-2726

Boudreau BP, Jørgensen BB (2001) The benthic boundary layer: transport processes and biogeochemistry. Oxford University Press, Oxford

Brenchley GA (1976) Predator detection and avoidance: ornamentation of tube-caps of Diopatra spp. (Polychaeta: Onuphidae). Mar Biol 38:179-188

Burnaford JL (2004) Habitat modification and refuge from sublethal stress drive a marine plant-herbivore association. Ecology 85:2837-2849

$>$ Callaway R (2006) Tube worms promote community change. Mar Ecol Prog Ser 308:49-60

Cape Cod Cooperative Extension (2007-2010) Barnstable Harbor water quality data, supported by Barnstable County and the South Eastern Massachusetts Aquaculture Center. http://www.capecodextension.org/MarinePrograms/

Crain CM, Bertness MD (2006) Ecosystem engineering across environmental gradients: Implications for conservation and management. Bioscience 56:211-218

Cuddington K, Hastings A (2004) Invasive engineers. Ecol Model 178:335-347

Cuddington K, Byers JE, Wilson WG, Hastings A (2007) Ecosystem engineers: plants to protists, Academic Press, Amsterdam

> Diaz RJ, Cutter GR, Able KW (2003) The importance of physical and biogenic structure to juvenile fishes on the shallow inner continental shelf. Estuaries 26:12-20

Dudley EC, Baker AJ, Cariello A, Leong KM, Ballantine A (1989) The occurrence of living mollusks on Diopatra tube-caps. Veliger 32:229-230

Eckman JE (1985) Flow disruption by an animal-tube mimic affects sediment bacterial colonization. J Mar Res 43: 419-435

- Eckman JE (1990) A model of passive settlement by plank- 
tonic larvae onto bottoms of differing roughness. Limnol Oceanogr 35:887-901

Eckman JE, Nowell ARM, Jumars PA (1981) Sediment destabilization by animal tubes. J Mar Res 39:361-374

Fager EW (1964) Marine sediments: effects of a tubebuilding polychaete. Science 143:356-358

> Fauchald K (1977) Polychaetes from intertidal areas in Panama, with a review of previous shallow-water records. Smithson Contrib Zool 221:1-81

Floeter SR, Behrens MD, Ferreira CEL, Paddack MJ, Horn $\mathrm{MH}$ (2005) Geographical gradients of marine herbivorous fishes: patterns and processes. Mar Biol 147: 1435-1447

Gleeson RA (2001-2006) Guana Tolomato Matanzas National Estuarine Research Reserve. Fort Matanzas water quality data. Research was conducted under an award from the Estuarine Reserves Division, Office of Ocean and Coastal Resource Management, National Ocean Service, National Oceanic and Atmospheric Administration. http://cdmo.baruch.sc.edu/

Huettel M, Gust G (1992) Impact of bioroughness on interfacial solute exchange in permeable sediments. Mar Ecol Prog Ser 89:253-267

Hurley D (1996-2004) Sapelo Island National Estuarine Research Reserve. Marsh Landing water quality data. Research was conducted under an award from the Estuarine Reserves Division, Office of Ocean and Coastal Resource Management, National Ocean Service, National Oceanic and Atmospheric Administration. http://cdmo. baruch.sc.edu/

Indian River Lagoonwatch (1996-2009) Indian River Lagoonwatch water quality data, supported by the Indian River Lagoon Program of St. John's River Water Management District and the US EPA. http://www.mrcirl.org/water/ watch.html

Irving AD, Connell SD (2006) Predicting understorey structure from the presence and composition of canopies: an assembly rule for marine algae. Oecologia 148:491-502

Kimbro DL, Grosholz ED (2006) Disturbance influences oyster community richness and evenness, but not diversity. Ecology 87:2378-2388

Luckenbach MW (1986) Sediment stability around animal tubes: the roles of hydrodynamic processes and biotic activity. Limnol Oceanogr 31:779-787

> Luckenbach MW (1987) Effects of adult infauna on new recruits: implications for the role of biogenic refuges. J Exp Mar Biol Ecol 105:197-206

Lumley T (2009) Thomas Lumley using Fortran code by Alan Miller. leaps: regression subset selection. R package version 2.9. http://CRAN.R-project.org/package=leaps

> Mangum CP, Cox CD (1971) Analysis of the feeding response in the onuphid polychaete Diopatra cuprea (Bosc). Biol Bull 140:215-229

Mangum CP, Santos SL, Rhodes WR (1968) Distribution and feeding in the onuphid polychaete, Diopatra cuprea (Bosc). Mar Biol 2:33-40

> Menge BA, Lubchenco J (1981) Community organization in temperate and tropical rocky intertidal habitats: prey refuges in relation to consumer pressure gradients. Ecol Monogr 51:429-450

Milliman JD, Pilkey OH, Ross DA (1972) Sediments of the continental margin off the Eastern United States. Geol Soc Am Bull 83:1315-1334

Myers AC (1972) Tube-worm-sediment relationships of Diopatra cuprea (Polychaeta: Onuphidae). Mar Biol 17:350-356
Oksanen J, Blanchet FG, Kindt R, Legendre P and others (2011). vegan: Community Ecology Package. R package version 1.17-9. http://CRAN.R-project.org/package=vegan

> Peckol P, Baxter D (1986) Population dynamics of the onuphid polychaete Diopatra cuprea (Bosc) along a tidal exposure gradient. Estuar Coast Shelf Sci 22:371-377

R Development Core Team (2010) R: A language and environment for statistical computing. R Foundation for Statistical Computing, Vienna

Siegel S, Castellan NJ Jr (1988) Nonparametric statistics for the behavioral sciences. McGraw-Hill, New York, NY

Skoog SY, Venn C, Simpson EL (1994) Distribution of Diopatra cuprea across modern tidal flats: implications for Skolithos. Palaios 9:188-201

Smith E, Buzzeli C, Lohrer A, Chipouras E, Shubauer-Berigan J (1996-2009) North Inlet Winyah Bay National Estuarine Research Reserve. Oyster Landing and Debbidue Creek water quality data. Research was conducted under an award from the Estuarine Reserves Division, Office of Ocean and Coastal Resource Management, National Ocean Service, National Oceanic and Atmospheric Administration. http://cdmo.baruch.sc.edu/

Smithsonian Marine Science Network (2006-2009) Smithsonian Marine Station Fort Pierce - Real Time Environmental Monitoring Program. Smithsonian Institution, Fort Pierce, Florida, USA. Interactive Oceanographics. http://nmnhmp.riocean.com/site.php? siteIndex=1

Stachowicz JJ, Hay ME (1999) Reducing predation through chemically mediated camouflage: indirect effects of plant defenses on herbivores. Ecology 80:495-509

- Stuart SA, Choat B, Martin KC, Holbrook NM, Ball MC (2007) The role of freezing in setting the latitudinal limits of mangrove forests. New Phytol 173:576-583

Therneau T, Atkinson B, Ripley B (eds) (2010) rpart: Recursive Partitioning. R package version 3.1-46. http://cran.rproject.org/web/packages/rpart/index.html

Thomsen MS, McGlathery K (2005) Facilitation of macroalgae by the sedimentary tube forming polychaete Diopatra cuprea. Estuar Coast Shelf Sci 62:63-73

> Thomsen MS, Gurgel CFD, Fredericq S, McGlathery KJ (2006) Gracilaria vermiculophylla (Rhodophyta, Gracilariales) in Hog Island Bay, Virginia: a cryptic alien and invasive macroalga and taxonomic correction. J Phycol 42:139-141

Thomsen MS, Wernberg T, Altieri A, Tuya F and others (2010) Habitat cascades: the conceptual context and global relevance of facilitation cascades via habitat formation and modification. Integr Comp Biol 50:158-175

Venables WN, Ripley BD (2002) Modern applied statistics with S. Springer, New York, NY

Virnstein RW, Carbonara PA (1985) Seasonal abundance and distribution of drift algae and seagrasses in the midIndian River Lagoon, Florida. Aquat Bot 23:67-82

Woodin SA (1978) Refuges, disturbance, and community structure: a marine soft-bottom example. Ecology 59: 274-284

Woodin SA (1981) Disturbance and community structure in a shallow water sand flat. Ecology 62:1052-1056

> Wright JP, Jones CG (2006) The concept of organisms as ecosystem engineers ten years on: progress, limitations, and challenges. Bioscience 56:203-209

Wright JP, Jones CG, Boeken B, Shachak M (2006) Predictability of ecosystem engineering effects on species richness across environmental variability and spatial scales. J Ecol 94:815-824 